\title{
Export Technological Sophistication of China: Measurement and Impact Factor
}

\author{
Peishan Fan \\ China Machinery Import and Export (Group) Co., Ltd., Beijing, China \\ Correspondence should be addressed to Peishan Fan; 195752635@qq.com
}

Received 19 August 2021; Revised 19 September 2021; Accepted 27 September 2021; Published 12 October 2021

Academic Editor: Daqing Gong

Copyright (c) 2021 Peishan Fan. This is an open access article distributed under the Creative Commons Attribution License, which permits unrestricted use, distribution, and reproduction in any medium, provided the original work is properly cited.

\begin{abstract}
What matters for China's future growth is not the volume of exports, but whether China will continue to enhance the export competitiveness of high-tech products. Using the export data of 25 countries from 1998 to 2019, this paper measures the export technological sophistication of machinery and transport equipment and constructs an empirical model to study the impact factors of export technological sophistication of machinery and transport equipment in China. The results show that the export technological sophistication is not high, although the export volume of machinery and transportation equipment is large. FDI, human capital, and the previous phase of export technological sophistication have a significant positive effect on the technological sophistication of export; however, the abundant natural resource has a significant negative effect. Finally, some countermeasures and suggestions are put forward based on the empirical results.
\end{abstract}

\section{Introduction}

China's growth was fueled by the reform and opening-up policy, seizing the opportunities that the world market offered. Abundant labor resources and low cost build the competitive advantage of China in the export of labor-intensive products. Since 2009, China's total exports have ranked first in the world for the following years. In 2019, China's total exports reached $\$ 2.5$ trillion, hitting a record high. Although China is a big trade country, it is far from being a strong trade country. For healthy and sustainable development, China needs to shift from high-speed development to high-quality development. When entering a new stage of development, it is necessary for China to improve the quality of exports and to promote the transformation and upgrading of exports. At present, China's export upgrade has made some progress. On the one hand, the coverage of China's export commodity becomes more extensive. The manufactured exports cover trading sectors from low-tech textiles to high-tech electronic products. On the other hand, the quality of China's commodity exports is constantly improving. The major exports gradually transform from primary products and resource-intensive products to all kinds of manufactured products and hightech products. And the added value of commodity exports is gradually increasing at the same time.

Export sophistication captures the export product quality and reflects the differences in technical content among export products. In 1984, Michaely first proposed the concept of export sophistication, which emphasizes the technical characteristics of a certain country's (region's) export. Rodirk [1] and Hausmann et al. [2] verified that the higher the sophistication of export, the stronger international competitiveness. The indicator of export technological sophistication provided evidence for China's export upgrade [1]. Increasing the share and competitiveness of high-tech products is the key to export upgrading. What matters for China's future growth is not the volume of exports, but whether China will continue to improve the export technology composition and enhance the export competitiveness of high-tech products. Although China's export sophistication has been greatly raised, there are still some issues worth discussing: (a) Comparing with itself, what is the trend for the export sophistication of China's high-tech products? Comparing with other counties, is the export sophistication of China's high-tech exports leading the 
world? (b) What factors influence the export sophistication of China's high-tech products? And what is the degree of impact factors on the export sophistication? Based on this, it is particularly important to study the export sophistication of China's export and its impact factors, not only for China but also for other developing countries.

The result shows that China's export volume of machinery and transportation equipment products is large, but the export technological sophistication is not high. Foreign direct investment, human capital, and previous phase of export technological sophistication have a significant positive effect on export sophistication; however, the abundant natural resource has a significant negative effect.

The remainder of this paper is structured as follows: Section 2 provides a brief overview of the related literature of export sophistication; Section 3 introduces the measurement of export sophistication and compares the indicator between China and other countries; Section 4 introduces the impact factors of export sophistication and conducts an empirical model; and Section 5 concludes the study.

\section{Literature Review}

The index of export technological sophistication reflects the productivity level associated with a country's (region's) export basket. In their seminal work, Rodrik [1] and Hausmann et al. [2] proposed the indicator of export technological sophistication. For each good, they generated an associated income/ productivity level called PRODY and then constructed the indicator of export sophistication called EXPY, by calculating the export-weighted average of the PRODY for that country (region). Hausmann et al. [2] argued that the export technological sophistication measures the quality of countries' export baskets and provided the evidence that the mix of goods had important implications for economic growth. Based on Rodrik and Hausmann's theory, Mishra et al. [3] conducted the index using GDP per capita instead of total factor productivity. And the regression result bore out that service export sophistication is positively associated with economic growth. Zheng and Wang [4] came to a similar conclusion, using the data of new energy industry.

China's export basket became significantly more sophisticated than before; however, there still remains a gap compared with other countries. Firstly, low-quality and lowtech products account for a large share of China's export. Schott [5] examined the relative sophistication of China's exports to the United States, which showed that China was specializing in lower-quality products. Xu [6] modified two measurement biases and found that China appeared much less as an outlier in the cross-country comparison of the sophistication of exports. Secondly, foreign entities have a more important contribution to the true improvement in China's export technology level, compared with domestic entities. Jarreau and Poncet [7] focused on the province and prefecture level and found that the export sophistication growth was limited to ordinary export activities undertaken by domestic firms. Koopman et al. [8] asserted that high sophisticated sectors such as electronic devices had particular low domestic content.
As the export sophistication has been an important determinant of China's rapid growth and also other developing countries' sustainable growth, the impact factor of export sophistication draws much attention. In terms of economic factors, Hausmann et al. [2] and Weldmicael [9] studied the effect of human capital on export sophistication, and the result showed that population size and GDP per capita had a significant positive effect on it. Foreign direct investment (FDI) also plays an important role in promoting export sophistication. Zhu et al. [10], Li et al. [11], and Li et al. [12] identified a positive effect of FDI on manufacturing export sophistication, which comes from the export share of foreign-invested enterprises (FIEs) and the privately owned enterprises (POEs). Zhang and Chen [13] pointed out that outward foreign direct investment (OFDI) only had a positive impact on export sophistication in the developed coastal region. However, there may exist a nonlinear effect from FDI on export sophistication exhibiting diminishing returns $[14,15]$.

As for the institutional factors, Rehman et al. [16] employed a robust dynamically simulated autoregressive distributed (DYS-ARDL) dynamic method and found that better infrastructure will be more beneficial for Chinese export sophistication and diversification. Atasoy [14] studied the positive effect of digitalization on export sophistication. Gan and Cheng [17] found that the exchange rate reform changed the effect of the $\mathrm{RMB}$ exchange rate on export complexity from significantly negative to significantly positive.

Beyond the above factors, Baliamoune-Lutz [15] provided evidence that exporting to developed economies enhances the sophistication of exports in exporting country. Mao and He [18] argued that environmental improvement associated with export upgrading in China had largely relied on changing product mix to avoid the environmental cost, exhibiting a significant displacement effect.

Based on the above literature, this paper draws on Rodrik's [1] measurement of export sophistication of a country and uses the data of Category 7 products under SITC classification. In addition, from the perspective of export technological sophistication, this paper studies the reasons for the change of China's export technology composition and puts forward corresponding suggestions.

\section{International Comparison of Export Technological Sophistication}

3.1. The Measurement of Export Technological Sophistication. Category 7 (machinery and transport equipment) and Category 8 (miscellaneous products) under the International Trade Standards Classification (SITC) are generally considered as high technical products. Under the structure of export, the manufactured exports almost cover the majority of exports of China. According to the China Statistical Yearbook, the amount of Category 7 and Category 8 exports accounted for $71.2 \%$ of China's total exports in 2019, with Category 7 accounting for $47.8 \%$. The high share of these two categories partially reflects the high-tech content of China's exports. The amount of China's exports under these two 
categories is larger than that of many developed countries, whether it implies that China leads the high-quality and high-tech export in the world. Based on the consideration, we take Category 7 products as an example to study China's export technological sophistication in high-tech products.

As for the measurement of export technological sophistication, this paper draws on the index of PRODY and EXPY proposed by Rodrik [1]. PRODY is the weighted sum of the per capita income level of countries exporting a given product; the definition of the product sophistication index (PRODY) is as follows:

$$
\operatorname{PRODY}_{i}=\sum_{j} \frac{x_{i j} / X_{j}}{\sum_{j}\left(x_{i j} / X_{j}\right)} Y_{j},
$$

where countries are indexed by $j$ and products are indexed by $i$. The weight $x_{i j} / X_{j}$ is the value share of the product in the country's overall export basket. $Y_{j}$ indexes the per capita GDP of country $j$. PRODY ${ }_{i}$ index captures the export technological sophistication of product $i$. The larger the $\mathrm{PRODY}_{i}$ is, the larger the investment proportion of technology factor in the product $i$ is. Since the per capita income level is closely related to the per capita GDP of a country or region, per capita GDP can be used to replace the per capita income level of a country when measuring technological sophistication.

EXPY for country $j$ is the weighted sum of the technological sophistication of all export products:

$$
\mathrm{EXPY}_{j}=\sum_{i} \frac{x_{i j}}{X_{j}} \mathrm{PRODY}_{i},
$$

where EXPY index captures the export technological sophistication of country $j$. Other symbols have the same meaning as formula (1).

EXPY cannot fully explain the true export competitiveness. On the one hand, based on formula (2), even if all other factors remain unchanged, the export technological sophistication will still rise with the rise of per capita GDP. On the other hand, when raising export technological sophistication of China's Category 7, the indicator of other countries is rising at the same time. In order to control the two biases above, this paper constructs the relative export technological sophistication as follows:

$$
\operatorname{REXPY}_{c}=\frac{\operatorname{EXPY}_{c}}{\left(\sum_{j} \operatorname{EXPY}_{j} / n\right)},
$$

where $\mathrm{REXPY}_{c}$ indexes the relative export technological sophistication of products in China and $n$ indexes the number of sample countries except China, namely, $n=24$. The remaining symbols are the same meaning as the formula (2). $\mathrm{REXPY}_{c}$ larger than 1 represents that the international competitiveness of China's Category 7 product is higher than the average level. On the contrary, $\mathrm{REXPY}_{c}$ less than 1 represents that the international competitiveness of China's Category 7 product is lower than the average level.

3.2. Data and Descriptive Statistics. Worldwide export data are necessary for measuring export sophistication. Given the availability of the data, we focus on the top 36 countries (regions) and take export data of Category 7 (machinery and transport equipment) from 1998 to 2019 as the sample. The sample countries (regions) and their proportion of exports in 2019 are shown in Table 1. The sample is highly representative, as their amount of Category 7 accounted for $90.7 \%$ of the world's total exports in 2019. Since some countries lack the export data in sample interval years, finally, 25 sample countries (or regions with * in Table 1) remain. These countries (regions) are China Mainland, the United States, Germany, Japan, the Netherlands, France, South Korea, Hong Kong, Italy, Mexico, Canada, Singapore, Spain, India, Switzerland, Australia, Poland, Saudi Arabia, Malaysia, Thailand, Brazil, Turkey, Indonesia, Sweden, and Denmark. The sample is highly representative and basically meets the research needs, since the total exports of the 25 sample countries account for more than $75 \%$ of the world's total exports in Category 7.

Therefore, to measure the export sophistication of Category 7 products, we finally use the export product data of 25 countries from 1998 to 2019, and products are classified by two bits based on SITC Rev.2. In Category 7, there are nine types of products under the two-bit code classification (called subcategory), and the export data under each subcategory of each country comes from the United Nations Commodity Trade Statistics Database (UNCOMTRADE). Per capita GDP data are collected from the World Development Indicators Database of World Bank and calculated in current US dollars.

\subsection{Results and Analysis}

3.3.1. Analysis of the Trend for China's Export Technological Sophistication. Using the subcategory and total export data of Category 7 from UNCOMTRADE and per capita GDP data from the World Development Indicators Database, the PRODY and EXPY are calculated. First, based on formula (1), the export technological sophistication of each subcategory in Category 7 from 1998 to 2019 is calculated (PRODY). Then, based on formula (2), the export technological sophistication of sample countries is calculated (EXPY). Figure 1 shows the trend for export technological sophistication of Category 7 in China from 1998 to 2019. China has experienced stable growth in the export technological sophistication of its export since 1998. More specifically, China underwent a stable level in export technological sophistication from 2002 to 2008, maintaining at 15,000 international dollars. After 2009, China experienced the most rapid rate of growth in sophistication, albeit a slight downside in 2014. In general, the export technological sophistication of China's Category 7 products increased from 12,428 international dollars in 1998 to 29,617 international dollars in 2019, more than double in 21 years. With the expanding volume of China's Category 7 exports, the result shows that the export technological sophistication continues to rise and the export structure continues to optimize. 
TABLe 1: Top 36 countries in terms of total exports of Category 7 in 2019.

\begin{tabular}{|c|c|c|c|c|c|}
\hline Rank & Country/region & Proportion (\%) & Rank & Country/region & Proportion (\%) \\
\hline 1 & China Mainland* & 13.71 & 19 & Switzerland* & 1.72 \\
\hline 2 & The United States* & 9.02 & 20 & Australia* & 1.46 \\
\hline 3 & Germany* & 8.19 & 21 & Vietnamese & 1.45 \\
\hline 4 & Japan* & 3.87 & 22 & Poland* & 1.38 \\
\hline 5 & The Netherlands* & 3.16 & 23 & Saudi Arabia* & 1.38 \\
\hline 6 & France ${ }^{*}$ & 3.05 & 24 & Malaysia* & 1.31 \\
\hline 7 & South Korea* & 2.97 & 25 & Thailand* & 1.28 \\
\hline 8 & Hong Kong* & 2.94 & 26 & Brazil* ${ }^{*}$ & 1.24 \\
\hline 9 & Italy* & 2.92 & 27 & Czech & 1.09 \\
\hline 10 & Britain & 2.57 & 28 & Turkey* & 0.99 \\
\hline 11 & Mexico* & 2.52 & 29 & Austria & 0.94 \\
\hline 12 & Canada* & 2.45 & 30 & Ireland & 0.94 \\
\hline 13 & Belgium & 2.44 & 31 & Indonesia* & 0.92 \\
\hline 14 & Russia & 2.34 & 32 & Sweden* & 0.88 \\
\hline 15 & Singapore* & 2.14 & 33 & Hungary & 0.67 \\
\hline 16 & The United Arab Emirates & 2.14 & 34 & Denmark* & 0.60 \\
\hline 17 & Spain* & 1.85 & 35 & Norway & 0.57 \\
\hline 18 & India* & 1.77 & 36 & Slovakia & 0.49 \\
\hline
\end{tabular}

Data resource: calculated according to relevant data of UNCOMTRADE.

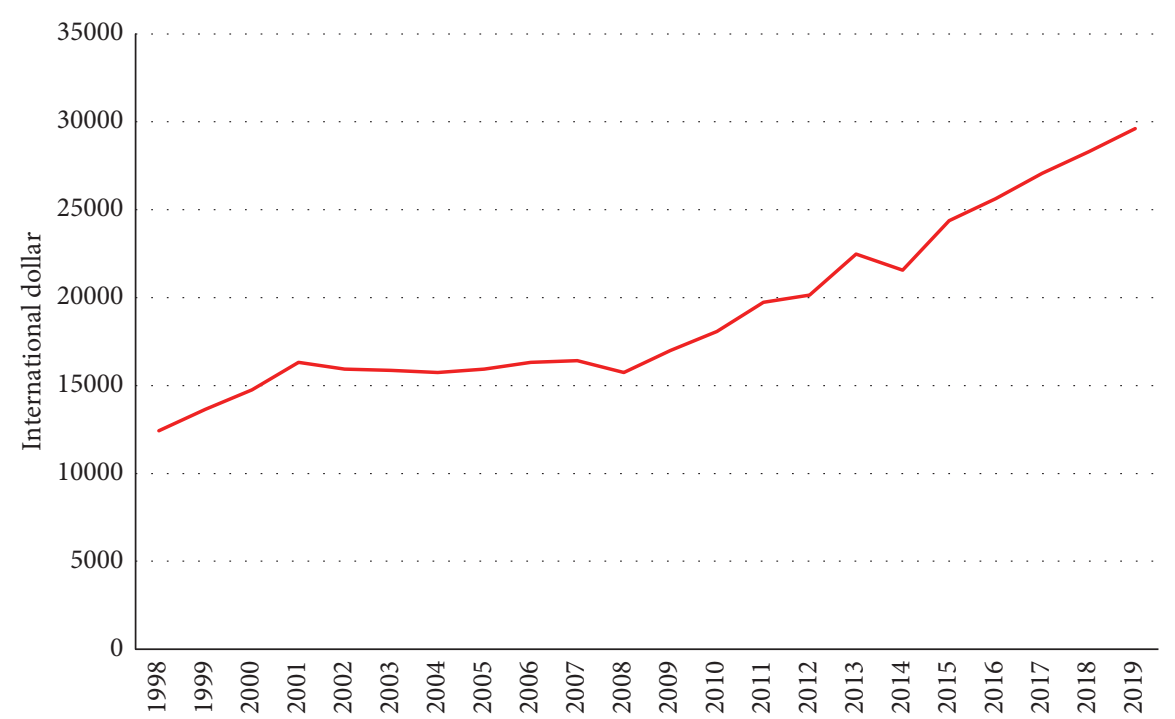

FIgURE 1: Export technological sophistication of China's machinery and transport equipment products from 1998 to 2019. Data resource: calculated according to relevant data of UNCOMTRADE.

3.3.2. Analysis of the Trend for World's Export Technological Sophistication. Besides the trend of China's export technological sophistication, this paper also analyzes the trends of the major regions' export technology level in the world. Figure 2 shows the trends for the logarithm of the export technological sophistication in major association (EU, NAFTA, and ASEAN). From 1998 to 2019, the trend for export technology level in major regions of the world was roughly the same. The average value of export technological sophistication in all regions showed an upward trend, and its numeric increased from 9.52 in 1998 to 10.44 in 2019. At the regional level, the export technological sophistication of EU's Category 7 products is significantly higher than the world average and that of North American Free Trade Area (NAFTA) is slightly higher than the world average, and the export technological sophistication of Category 7 products from Association of Southeast Asian Nations (ASEAN) countries is lower than the world average.

3.3.3. International Comparison. The relative export technological sophistication (REXPY) reflects the international competitiveness gap of Category 7 products between China and other countries. Based on formula (3), we compare China's export competitiveness of machinery and transportation equipment with other countries.

Figure 3 shows the trend of the relative export technological sophistication of China's machinery and transportation equipment. China's relative export technological sophistication of Category 7 has been less than 1 since 1998. Although China 


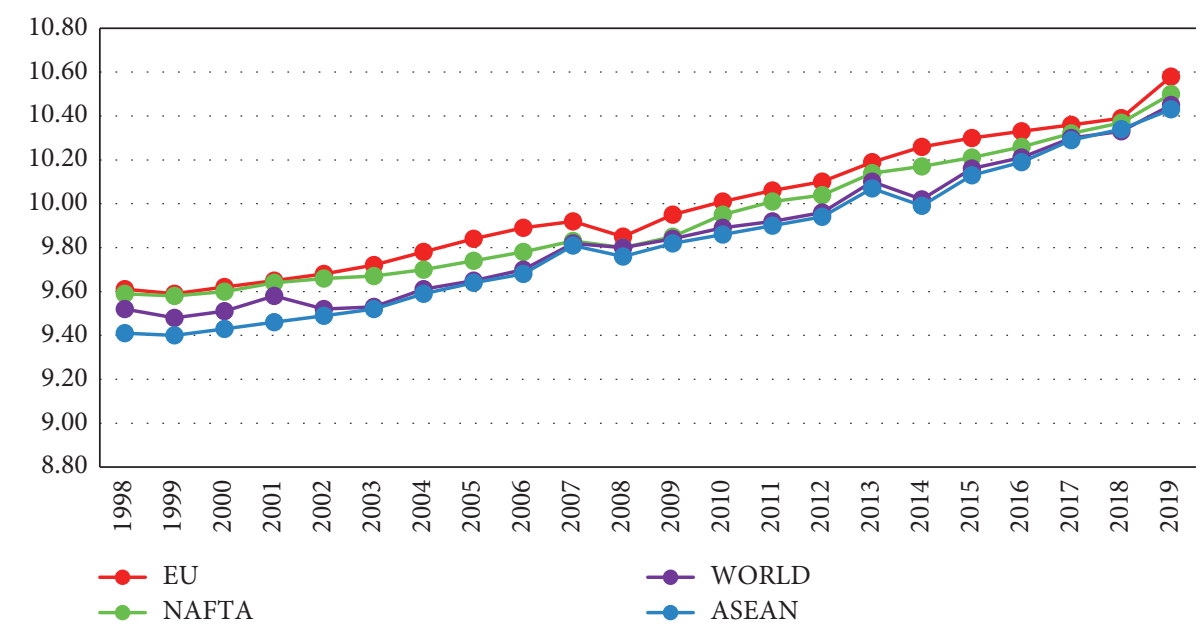

FIGURE 2: Export technological sophistication of the world's machinery and transportation equipment from 1998 to 2019. Data resource: calculated according to relevant data of UNCOMTRADE.

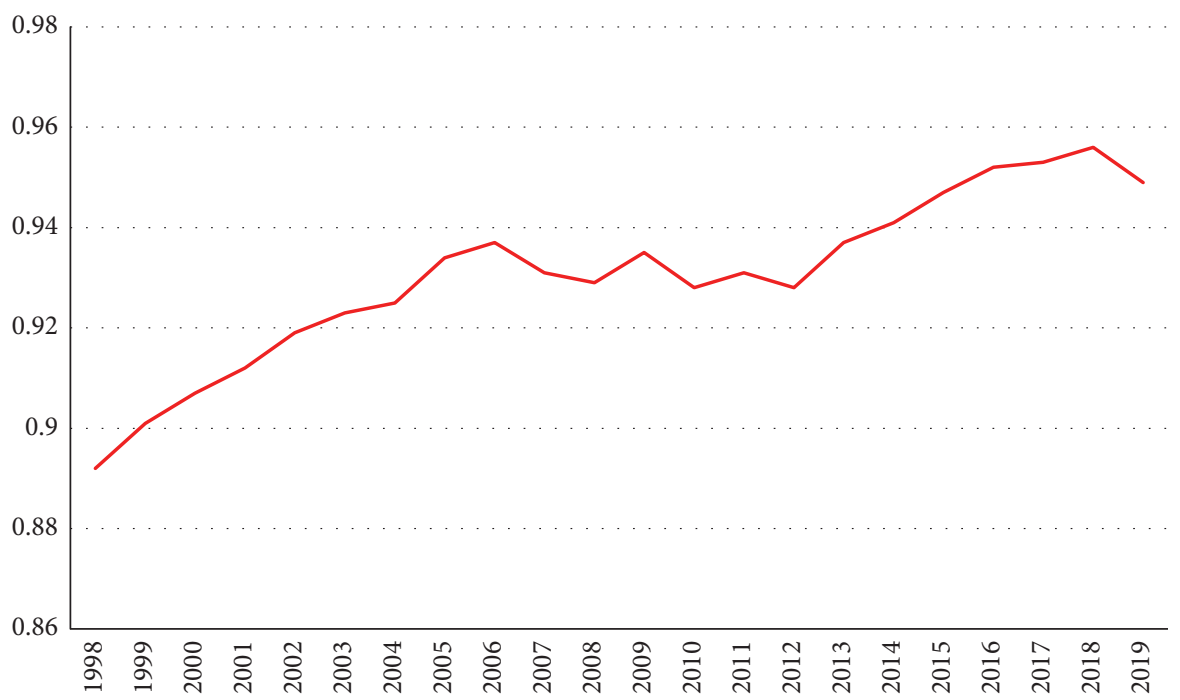

FIgURE 3: The trend for relative export technological sophistication of China's machinery and transportation equipment from 1998 to 2019. Data resource: calculated according to relevant data of UNCOMTRADE.

enjoys a scale advantage on the export of machinery and transportation equipment, it shows that China's export technological sophistication has been at a lower level compared with other main exporters. And the international competitiveness of China's high-tech products is still not strong. As for the trend of the indicator in recent years, the index showed a gradual increase from 1998 to 2006, then a fluctuation from 2007 to 2012 , finally a gradual increase after 2013. In 2019, the relative export technological sophistication has risen to 0.95 , but there is still a gap with the world average level. China's overall export technology level is still below the middle level.

Table 2 shows the export technological sophistication ranking of 25 sample countries in machinery and transportation equipment during 1998 and 2019. It shows that the export technological sophistication ranking of China's Category 7 product ranked the 23rd among all sample countries in 1998; however, China's ranking only rose 3 places to the 20th in 2019. It is a distinct contrast to China's export volume ranking first in the world, indicating that the technology content of China's machinery and transportation equipment export is still not high. The technological sophistication is not only far lower than that of the United States, Germany, Japan, France, and other major developed countries in the world but also significantly lower than that of South Korea, Mexico, and other major emerging industrial economies. Therefore, what matters for China's future growth is not the volume of exports, but whether China will continue to improve the export technology composition and enhance the export competitiveness of hightech products.

\section{Impact Factors of Export Technological Sophistication}

4.1. Model Construction. According to classical trade theory, international trade is based on the international division of labor among countries. Every country concentrates on 
TABLE 2: Rank change in export technological sophistication of machinery and transportation equipment in sample countries.

\begin{tabular}{|c|c|c|c|c|c|}
\hline Country/region & Rank in 1998 & Rank in 2019 & Country/region & Rank in 1998 & Rank in 2019 \\
\hline China Mainland & 23 & 20 & Spain & 3 & 9 \\
\hline Germany & 9 & 7 & Malaysia & 24 & 24 \\
\hline The United States & 16 & 13 & Poland & 13 & 15 \\
\hline Japan & 15 & 11 & Sweden & 8 & 10 \\
\hline South Korea & 20 & 17 & Australia & 12 & 4 \\
\hline Hong Kong & 22 & 25 & Switzerland & 4 & 8 \\
\hline France & 11 & 5 & India & 5 & 12 \\
\hline Mexico & 17 & 19 & Brazil & 6 & 2 \\
\hline Singapore & 19 & 22 & Turkey & 18 & 14 \\
\hline Italy & 7 & 1 & Indonesia & 25 & 23 \\
\hline The Netherlands & 14 & 18 & Denmark & 10 & 3 \\
\hline Canada & 1 & 6 & Saudi Arabia & 2 & 16 \\
\hline Thailand & 21 & 21 & & & \\
\hline
\end{tabular}

Data resource: calculated according to relevant data of UNCOMTRADE.

producing products with comparative advantages and exchanges them internationally. Resource endowment is the basis of the labor division. According to their own favorable production conditions, every country conducts international labor division and exchange activities. So that they can make the best use of human capital and physical capital, promote the growth of productivity, and then improve the technological sophistication of exports. The Technology Gap Theory points out that technological advantage can not only provide an export advantage but also improve the export technological sophistication of a country. Based on the above theory and relevant literature, this paper constructs an empirical model to analyze the impact factors of export technological sophistication. The specific model is as follows:

$$
\begin{aligned}
\operatorname{LnEXPY}_{i}= & \beta_{0}+\beta_{1} \operatorname{LnFDI}_{i}+\beta_{2} \operatorname{LnEdu}_{i}+\beta_{3} \operatorname{LnRD}_{i} \\
& +\beta_{4} \operatorname{LnEndow}_{i}+\beta_{5} \operatorname{LnEXPY}(-1)_{i}+\varepsilon,
\end{aligned}
$$

where the explained variable is the export technological sophistication (EXPY) of China's machinery and transportation equipment from 1998 to 2019 measured above. Explanatory variables mainly include foreign direct investment (FDI), human capital (Edu), research and development level (RD), natural resource endowment (Endow), and the previous phase of export technological sophistication (EXPY-1). The five explanatory variables are mainly based on the following mechanisms to influence export sophistication.

FDI is an important avenue of technology spillover. Different from indirect investment, FDI is not only the flow of capital between countries or regions but also the flow of technology, knowledge, operation and management experience, and other factors, which can improve the technological progress and economic development of host countries. The effect of FDI on the export technological sophistication can be divided into two aspects: direct and indirect. Firstly, FDI enterprises increase the proportion of capital-intensive and technology-intensive products by exporting high-tech products directly. It is conducive for the host country to optimize the technical structure of export. Secondly, FDI indirectly improves technology innovation and optimizes the structure of export through technology diffusion and spillover, such as the flow of human capital. FDI data comes from China Statistical Yearbook.

Education and R\&D are important factors for a country to carry out independent innovation and knowledge innovation. Through knowledge accumulation, one country can improve the level of productivity directly and thereby can raise the export technological sophistication. From the perspective of technology spillover, the technology absorption and innovation capacity of a country are determined by human capital and R\&D level. Particularly for relatively backward developing countries, technology spillover can improve technology innovation and then improve the technological sophistication of export products. Education provides a lasting driving force for a country to carry out innovation, which can not only improve the creativity of talents but also cultivate the environment for innovation $[19,20]$. In this paper, the higher education enrollment rate indexes human capital (variable Edu), and the ratio of R\&D expenditure to GDP indexes a country's R\&D and scientific and technological level (variable RD). In line with previous pieces of literature, it is expected that there is a positive effect of these two variables on EXPY. The data of higher education enrollment rate comes from China Labor Statistical Yearbook, and the data of variable RD comes from China Science and Technology Statistical Yearbook.

Natural resources are the most basic input for production and technological progress. Abundant natural resources can improve a country's income level, which is conducive to raise the export technological sophistication. On the other hand, due to the scarcity and limitation of resources, resource-intensive industries in a country with abundant natural resources will absorb a large amount of physical and human capital, which will hinder the development of high-tech industries. Therefore, it is not clear whether abundant natural resources will be a blessing or a curse for the improvement of export structure and economic development. Energy use per unit of GDP indexes the natural resource endowment, and data comes from the 
World Development Indicators Database of the World Bank.

Export technology level of the previous phase: the new trade theory points out that enterprises can successfully enter the international market only after overcoming all kinds of sunk costs. With the expanding of export volume and the accumulation of experience, all kinds of information costs related to the local market will decrease, which makes the export behavior of enterprises have a strong characteristic of sustainability. The previous research shows that the previous phase of export technology level may affect the next phase of export technology level. Therefore, EXPY (-1) represents the previous phase of export technological sophistication included in the empirical model (4).

4.2. Regression Analysis. In this paper, we conduct the empirical model to study the main impact factors of China's export technological sophistication as well as the degree of impact. The autocorrelation of the series needs to be tested to avoid the occurrence of "false regression" when employing the data structure of the time series. Table 3 shows the ADF test result, which is used to test the autocorrelation of time series data. From the results of the ADF test, we find that all variables are first-order stable.

We employ stepwise regression to test the stability of model regression. Table 4 shows the results of model regression. In all of the six models, the variable Edu was regressed, and its coefficient is positive at the significance level of $1 \%$ or $5 \%$. It shows that education level plays a decisive role in China's export technological sophistication; that is, the higher the education level, the higher the export technological sophistication.

In model 2 of Table 4, the coefficient of FDI is positive but insignificant, and the regression result is not good. Therefore, the influence of natural resources (Endow) factor is added on the basis of model 2. In model 3 of Table 4 , the coefficient of FDI is positive and significant at the level of $5 \%$, which is consistent with our expectation. The result shows that FDI has a positive effect on the export technology level. On the one hand, since most of the FDI comes from developed countries that are relatively advanced in economy and technology, their products are generally considered high-tech products. On the other hand, enterprises in the host country can promote the technical level of their own products through technology spillover and technology absorption, which indirectly raises the export technological sophistication. However, Endow is negative and significant at the level of $10 \%$, which indicates that the curse of natural resources (curse of natural resources: abundant natural resources can not only provide financial support and material guarantee for the production of high-tech products but also squeeze out the production of high-tech products, which is not conducive to the upgrading of industrial structure and export structure) exists from the perspective of the technical structure of exports.

Model 4 of Table 4 tested the influence of human capital (Edu), natural resources (Endow), and the previous phase of
TABLE 3: Result of ADF test.

\begin{tabular}{lccc}
\hline Variable & ADF statistic & ADF statistical threshold & Prob. \\
\hline LEXPY & 0.4102 & -2.6561 & 0.982 \\
$\Delta$ LEXPY & -3.0674 & -2.6584 & 0.055 \\
LFDI & 0.6211 & -2.6561 & 0.989 \\
$\Delta$ LFDI & -3.9775 & -2.6614 & 0.012 \\
LEdu & -2.1218 & -2.6671 & 0.294 \\
$\Delta$ LEdu & -3.0557 & -2.6671 & 0.041 \\
RD & 1.2469 & -2.6561 & 0.987 \\
$\Delta$ RD & -3.6903 & -2.6614 & 0.024 \\
LEndow & -2.4344 & -2.6671 & 0.379 \\
$\Delta$ LEndow & -3.0662 & -2.6671 & 0.105 \\
LEXPY $(-1)$ & -0.2471 & -2.6614 & 0.854 \\
$\Delta$ LEXPY $(-1)$ & -4.1538 & -2.6671 & 0.109 \\
\hline
\end{tabular}

Note: ADF statistical threshold is at $10 \%$ significance level. " $\Delta$ " represents the first-order differential of variables.

export technological sophistication. The coefficient of EXPY $(-1)$ is significantly positive under $1 \%$ level, which shows that the previous phase of export technological sophistication affects the next phase of the export technological sophistication. The coefficient of Endow is negative and significant at the level of $5 \%$. The result shows that abundant natural resources may lead a country to focus on low-tech and resource-intensive products, instead of the accumulation of physical and human capital.

We added the R\&D investment (RD) in model 5 of Table 4. We found the positive effect of human capital and $\mathrm{R} \& \mathrm{D}$ level on export technological sophistication, which is consistent with our prediction. But the coefficient of $R \& D$ levels failed to pass the test of significance. Therefore, compared with increasing the $\mathrm{R} \& \mathrm{D}$ investment, it is more advantageous to enhance a country's export technology level by improving the level of education or increasing human capital investment. One possible explanation is that the lack of high-end technology researchers in China, which may result in partial research projects without declaration, and finally R\&D investment shows a limited contribution to the growth of exports technological sophistication.

In model 6 of Table 4, the RD was ignored and the rest of variables were regressed. The coefficient of Edu, FDI, and EXPY $(-1)$ is significantly positive; however, the coefficient of Endow is significantly negative. The result indicates that education level, the previous phase of export technological sophistication, and FDI have a positive effect on export technological sophistication; however, rich natural resources have a negative effect on export technological sophistication. Since all variables in the model are first-order stationary, we also need to test whether the residual of the model after regression is stationary. According to the results of the ADF test, the residual of model 6 is stable at the level of $1 \%$; that is, the conclusion we draw from model 6 is credible.

In model 4, model 5, and model 6 , we find that the coefficient of EXPY $(-1)$ is large, and all of them are significant at the level of $1 \%$. The result indicates that the previous phase of export technological sophistication has a great influence on the next phase of export technological sophistication. One possible explanation is the persistence of export behavior. The investment cost of enterprises in the 
TABLE 4: Model regression results.

\begin{tabular}{lcccccc}
\hline Variable & Model 1 & Model 2 & Model 3 & Model 4 & Model 5 & Model 6 \\
\hline LEdu & $0.274^{* * *}(7.25)$ & $0.258^{* *}(4.14)$ & $0.399^{* * *}(4.53)$ & $0.307^{* * *}(3.98)$ & $0.266^{* * *}(3.27)$ & $0.319^{* *}(4.14)$ \\
LFDI & & $0.286(1.38)$ & $0.307^{* *}(2.54)$ & & $0.319^{* * *}(2.96)$ \\
LEndow & & & $-0.795^{* *}(-2.54)$ & $-0.653^{* *}(-2.71)$ & $-0.505^{* *}(-2.99)$ & $-0.694^{* * *}(-3.05)$ \\
LEXPY (-1) & & & & $0.952^{* * *}(6.08)$ & $0.825^{* * *}(5.43)$ & $0.771^{* * *}(3.29)$ \\
RD & & & & & $5.028(0.56)$ & 0.979 \\
R-squared & 0.859 & 0.874 & 0.902 & 0.957 & 0.975 \\
DW stat & 0.345 & 0.528 & 0.756 & 1.309 & 1.747 & 1.853 \\
\hline
\end{tabular}

Note. ${ }^{*},{ }^{* *}$, and ${ }^{* * *}$, respectively, represent the significance level of $10 \%, 5 \%$, and $1 \%$, and the results retain two decimal places.

export market is hard to withdraw. As long as enterprises choose to enter the market, they will continue to maintain the export behavior. In addition, the improvement of the previous phase of export sophistication is conducive to the enterprises to enrich the export experience, to increase the volume of exports in the process of production and exportation, so as to improve the technical level of export products.

\section{Discussion}

Using the export data of 25 countries from 1998 to 2019, this paper measures the export technological sophistication of machinery and transportation equipment products. To study the impact factors of the export technological sophistication of machinery and transportation equipment products of China, we conducted the empirical model. The result shows that although China's export volume of machinery and transportation equipment products is large, the export technological sophistication is not high. Foreign direct investment, human capital, and the previous phase of export technological sophistication have a significant positive effect on export technological sophistication; however, the abundant natural resource has a significant negative effect on export technological sophistication. Based on the above empirical results, we suggest that the export technology level of China can be optimized from two levels: the government and the enterprise.

(1) Government level: build a good external environment for rising the export sophistication.

Government can promote independent innovation through the supply side and the demand side based on the basic principles of economics, including R\&D investment subsidies and tax reduction [3]. Firstly, China's government is supposed to attach importance to education and increase investment in education, for example, adhering to the strategy of reinvigorating China through science and education, strengthening the nation through human resource development, and realizing scientific and technological progress through the accumulation of human capital. Secondly, China's government is supposed to improve trade openness and reduce trade barriers, such as introducing foreign direct investment actively so as to make full use of the important role of FDI in technology spillover and diffusion. Finally,
China's government is supposed to increase the $\mathrm{R} \& \mathrm{D}$ investment, support high-tech industries, and encourage enterprises to carry out technology innovation activities, for example, carrying out tax policies for R\&D investment, tax rebate policy for exports of high-tech products, exemption of patent application fee for emerging industries, and reward for patents granted. In addition, the government can also encourage enterprises and research institutions to cooperate with schools, which has strategic significance to optimize the export structure and promote economic growth.

(2) Enterprise level: continuously introduce high-quality talents, increase investment in $\mathrm{R} \& \mathrm{D}$, and inspire technical innovation.

Many practices have proved that only introducing foreign advanced technology cannot improve the export technological sophistication in the long run. On the one hand, the enterprise is supposed to attach importance to talent training, for example, discovering and introducing high technical personnel, paying attention to improve employees' intelligence and ability, encouraging employees to carry on the independent innovation, and improving the staff's productional and professional skills. Thereby, enterprise can improve production efficiency and the overall profits and finally improve product quality. On the other hand, the enterprise is supposed to become the subject of independent $\mathrm{R} \& \mathrm{D}$, for example, increasing $\mathrm{R} \& \mathrm{D}$ investment, carrying out independent innovation on the premise of absorbing foreign advanced technologies, and inventing products with independent intellectual property rights.

There are some limitations to this work. Firstly, the missing data limited the sample size of the empirical model, which may reduce the validity of the results. Secondly, Category 7 products may require further segmentation when representing high-tech products. Future work can hopefully further explore which means should government adopt to upgrade the export structure. Direct administrative intervention may be detrimental to enterprise investment and innovation, and lack of administrative intervention may miss the opportunity of economic development. The impact of administrative intervention mentioned above on export sophistication remains to be discussed. 


\section{Data Availability}

All the data in the paper could be accessed by request.

\section{Conflicts of Interest}

The author declares no conflicts of interest.

\section{References}

[1] D. Rodrik, "What's so special about China's exports?" China \& World Economy, vol. 14, no. 5, pp. 1-19, 2006.

[2] R. Hausmann, J. Hwang, and D. Rodrik, "What you export matters," Journal of Economic Growth, vol. 12, no. 1, pp. 1-25, 2007.

[3] S. Mishra, S. Lundstrom, and R. Anand, Service Export Sophistication and Economic Growth, Social Science Electronic Publishing, Rochester, NY, USA, 2011.

[4] H.-H. Zheng and Z.-X. Wang, "Measurement and comparison of export sophistication of the new energy industry in 30 countries during 2000-2015," Renewable and Sustainable Energy Reviews, vol. 108, pp. 140-158, 2019.

[5] P. K. Schott, "The relative sophistication of Chinese exports," Economic Policy, vol. 53, pp. 6-49, 2008.

[6] B. Xu, "The sophistication of exports: is China special?" China Economic Review, vol. 21, no. 3, pp. 482-493, 2010.

[7] J. Jarreau and S. Poncet, "Export sophistication and economic growth: evidence from China," Journal of Development Economics, vol. 97, no. 2, pp. 281-292, 2011.

[8] R. Koopman, Z. Wang, and S.-J. Wei, "Estimating domestic content in exports when processing trade is pervasive," Journal of Development Economics, vol. 99, no. 1, pp. 178-189, 2012.

[9] E. Weldemicael, "Technology, trade costs and export sophistication," The World Economy, vol. 37, no. 1, pp. 14-41, 2014.

[10] S. J. Zhu, X. L. Fu, and M. Y. Lai, "What drives the export sophistication of countries," SLPTMD Working Paper, vol. 33, 2010.

[11] Y. N. Li, M. K. Yang, and L. M. Zhu, "FDI liberalization and export sophistication: evidence from China," Japan and the World Economy, vol. 59, Article ID 101086, 2021.

[12] C. Li, C. Y. Liu, and J. Zhao, "The effects of inward and outward foreign direct investment on manufacturing export sophistication in China," Applied Economics Letters, 2020.

[13] S. Zhang and C. Chen, "Does outward foreign direct investment facilitate China's export upgrading?" China \& World Economy, vol. 28, no. 5, pp. 64-89, 2020.

[14] B. S. Atasoy, "The determinants of export sophistication: does digitalization matter?" International Journal of Finance \& Economics, 2020.

[15] M. Baliamoune-Lutz, "Trade sophistication in developing countries: does export destination matter?" Journal of Policy Modeling, vol. 41, no. 1, pp. 39-51, 2019.

[16] F. U. Rehman, E. Ahmad, M. A. Khan, J. Popp, and J. Olah, "Does trade related sectoral infrastructure make Chinese exports more sophisticated and diversified?" Sustainability, vol. 13, no. 10, 2021.

[17] S. Gan and D. Cheng, "Exchange rate appreciation, R\&D, and export sophistication: evidence from China," The Journal of International Trade \& Economic Development, vol. 29, no. 2, pp. 237-246, 2020.
[18] X. Mao and C. He, "Export upgrading and environmental performance: evidence from China," Geoforum, vol. 86, pp. 150-159, 2017.

[19] S. Jeong and I. Choi, "Cognitive bias in decision making according to change of tax policy: an exploratory study," Journal of System and Management Sciences, vol. 9, no. 4, pp. 127-137, 2018.

[20] F. A. Ogedengbe, "Management of educational organization: the effectiveness of soft skill on rejuvenating education curriculum," Journal of Logistics, Informatics and Service Science, vol. 6, no. 1, pp. 15-37, 2019. 